\title{
IDENTITAS TIONGHOA-INDONESIA MELALUI HERMENEUTIKA TIPOLOGI BONGPAY DI BONG MUNTANG-TANJUNG BANYUMAS
}

\author{
Tri Asiati \\ Program Studi D3 Bahasa Mandarin, Universitas Jendral Soedirman, Purwokerto \\ asiatitri@yahoo.com
}

\begin{abstract}
Abstrak
Istilah Tionghoa-Indonesia mengimplikasikan posisi dan kontribusi etnis Tionghoa dalam dinamika kebudayaan Indonesia, yang mana istilah ini merupakan adabtasi mereka terhadap Indonesia sebagai tanah air dan bukan sebagai tujuan migrasi. Mereka tetap menjaga dan melestarikan budaya Tionghoa melalui ekspresi dan eksistensi penghormatan keturunan terhadap leluhur yang diwujudkan pada Bongpay. Dalam signifikansi ini, Bongpay bukan sebagai penanda kesedihan akan perpisahan, melainkan ekspresi konsepsi identitas Tionghoa terhadap leluhur melalui keragaman tipologinya. Dengan menggunakan pendekatan hermeneutika sebagai metode penafsiran data dalam rangka menjelaskan kekhasan identitas mereka sebagai bagian dari masyarakat Indonesia berbasis pada Bongpay sebagai artefak kebudayaan Tionghoa, eksistensi Tionghoa-Indonesia, dan pandangan masyarakat Indonesia terkait dengan keberadaan mereka.
\end{abstract}

Kata Kunci: Tipologi, Bongpay, hermeneutics, identitas, dan penafsiran.

\begin{abstract}
Chinese-Indonesian term implies Chinese position and contribution to Indonesian cultural dynamic. This term refers to their adaptation in Indonesia as homeland instead of migrating destination. Nevertheless, they keep on taking care and preserving the bond with the Chinese by expression and the existence of tribute devoted to the ancestors which showed as Bongpay. In this significance, Bongpay is not merely sadness marker of a farewell, but the expression of Chinese conception to honor theirs ancestors with various typologies. In this ways, using hermeneutic method as a data interpretation to totality explain about theirs particular identity as a part of Indonesian society based on typology of Bongpay likely cultural artifact, Chinese existence, and society response.
\end{abstract}

Keywords: typology, Bongpay, hermeneutics, identity, and interpretation.

\section{A. PENDAHULUAN}

Istilah Tionghoa-Indonesia saat ini merupakan transformasi heterogenitas ${ }^{1}$ identitas Tionghoa yang berdiaspora ${ }^{2}$. Perubahan tersebut tentunya berdampak pada cara pandang mereka dimana Indonesia menjadi tanah air dan bukan lagi tujuan migrasi sebagaimana

\footnotetext{
${ }^{1}$ https://icssis.files.wordpress.com/2012/05/09102012-52.pdf

${ }^{2}$ https://kbgmrk.wordpress.com/.../bermain-main-dengan-teks- "representasi-kaum-pingiran
} 
sejarah menerangkan gelombang kedatangan leluhur etnis Tionghoa di Nusantara ${ }^{3}$ dan berdampak pada dikotomi identitas Totok dan Peranakan. Menurut Ibrahim (2012) Totok berorintasi pada relasi sejarah mereka dengan Tiongkok sebagai asal-usulnya, dan berpengaruh pada orientasi politik terhadap tanah leluhurnya. Sementara Peranakan mengacu pada kelahiran di luar daratan Tiongkok dan berakibat pada proses adabtasi dengan Indonesia sebagai tanah air. Dikotomi Totok dan Peranakan akhirnya mengarahkan orientasi politik mereka terhadap Tiongkok dan kekawulanan pemerintahan Hindia-Belanda atau nasionalisme Indonesia.

Dihadapkan pada polemik kontradiktif terkait dengan identitas Tionghoa-Indonesia dari sejarah kekuasaan pemerintah Hindia-Belanda yang memposisikan mereka sebagai golongan ke-dua ${ }^{4}$ hingga diskriminasi pemerintahan Orde Baru melalui politik asimilasinya ${ }^{5}$ melatarbelakangi dinamika perubahan identitas mereka. Ditambah lagi SARA dan propaganda komunisme yang menyebabkan insecurity ${ }^{6}$. Dampaknya, etnis Tionghoa-Indonesia

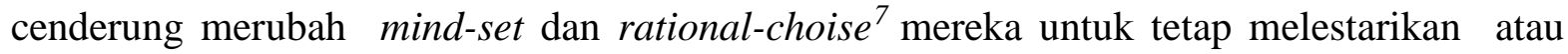
meninggalkan kebudayaan Tionghoa selaras dengan realita.

Perubahan mind-set dan rational-choise etnis Tionghoa didorong oleh insecurity dan diskrimanasi memposisikan mereka pada situasi (ingroup $)^{8}$. Hal ini sejalan dengan pemikiran Krizan dan Baron (2007) yang mengungkapkan secara psikologis individu dari kelompok sosial tertentu akan menempatkan nilai-nilai kelompoknya sebagai identitas sosial, sementara akan bersikap sebaliknya pada kelompok lain (outgroup). Atas dasar inilah mereka dihadapkan pada realita untuk bersinergi dengan kebudayaan barat sebagaimana Wang dalam Christian (2017) mengungkapkan tentang teori multi identitas etnik Tionghoa di Asia Tenggara. Ia menjelaskan tentang identitas nasional (national identity), identitas komunal (communal identity), identitas historis (historical identity), identitas budaya (cultural identity), dan identitas kelas (class identity) yang terjadi pada etnik Tionghoa Asia Tenggara. Keseluruhan konsep tersebut merujuk pada budaya sebagai ujung tombak dinamika, karena identitas Tionghoa Asia Tenggara kini tergolong identitas Tionghoa modern ${ }^{9}$ berbasis budaya barat dan berdampak pada gradasi maupun diferensiasi budaya antar generasi.

\footnotetext{
${ }^{3}$ http://wacana.ui.ac.id/index.php/wjhi/article/viewFile/271/258

4 http://fadhil- nugroho.blogspot.co.id/2012/04/jurnal-stratifikasi-sosial-bahan-dukung.html

5 journal.ui.ac.id/index.php/jai/article/download/3464/2744

6 ink.library.smu.edu.sg > ... > SOSS > SOSS_RESEARCH > 1202

${ }^{8}$ Ibid

${ }^{8}$ Ibid

${ }^{9}$ http://jurnal-apsmi.org/index.php/CM/article/viewFile/11/7
} 
Gradasi maupun diferensiasi identitas Tionghoa-Indonesia modern nampak pada konsep kematian yang cenderung bergeser dari tradisi kuno ke tradisi barat sebagaimana konsep dan filosofi Tionghoa dalam pandangan Konghuchu ${ }^{10}$. Kematian adalah relasi manusia dengan penguasa alam atau kekuatan-kekuatan lain yang mengatur kehidupannya dan berlaku adanya; reinkarnasi (cut sie), hukum karma (ko kut), upacara ziarah kubur (ce'ng be'ng), penghormatan pada leluhur dan orang pandai (tuapekong), papan nisan (bongpay), dan amalan dunia sebagai tabungan pada kehidupan kekal ${ }^{11}$. Dalam pandangan Tionghoa kuno, kematian bukan sebuah nuansa kesedihan akan putusnya jalinan kekeluargaan, melainkan kehidupan lanjutan. Lín dan Niè dalam Sasmita dan Tulistyantoro (2014) menjelaskan tentang konsepsi arwah leluhur yang bebas dan memiliki kekuatan untuk mempengaruhi hal-hal menguntungkan dan merugikan manusia, sehingga keberadaannya mutlak untuk dipuja.

Konsep kehidupan arwah leluhur yang dapat berpengaruh pada keberkahan keturunan dalam tradisi Tionghoa mengorientasikan mereka untuk senantiasa melakukan penghormatan dan pemujaan, salah satunya dengan memilih lahan yang tepat untuk makam dan juga Bongpay (papan nisan). Bruun (2008) mengemukakan bahwa daya baik makam akan berpengaruh pada keturunannya dan dipercaya hanya berdasarkan pada keutuhan tubuh jenazah. Sedangkan Jiang (2006) mengungkapkan Bongpay atau (Mu-bei) adalah sebutan papan nisan dalam dialek Hokkian serta menjadi bagian terpenting dalam tradisi Tionghoa ${ }^{12}$. Berbahan dasar batu alam, marmer, maupun granit dengan tulisan-tulisan dalam karakter Han kuno atau Fantizi (繁体字) ${ }^{13}$ serta tatacara pembacaan yang berbeda ${ }^{14}$, Bongpay mengandung makna maupun nilai artistik tersendiri. Selain menuliskan riwayat mendiang, Bongpay juga merepresentasikan bakti keturunan. Raharjopun (2012) menambahkan konsep makam Tionghoa tidak terlepas dari Feng-Shui ${ }^{15}$, karena masyakat Tionghoa percaya bahwa makam merupakan tempat bersemayamnya jenazah dengan arwah yang abadi dan akan mengawasi serta mengayomi keturunannya.

Berbasis pada konsep pemujaan leluhur Tionghoa berupa Bongpay yang terletak di kompleks Bong Muntang-Tanjung Banyumas, kajian ini terfokus pada pergeseran identitas

\footnotetext{
10 https://media.neliti.com/media/publications/41957-ID-agama-khonghucu-sejarah-ajaran-dankeorganisasiannya-di-pontianak-kalimantan-bar.pdf

${ }^{12}$ http://digilib.mercubuana.ac.id/manager/n!@file_skripsi/Isi1893295104511.pdf

${ }^{12}$ web.budaya-tionghoa.net/index.php/item/719-bagian-dalam-kuburan-tionghoa

${ }^{13} \mathrm{https}: / / \mathrm{www}$. britishmuseum.org/pdf/Chinese_language_1109.pdf

${ }_{15}$ jurnal.upnyk.ac.id/index.php/komunikasi/article/viewFile/83/87

15 https://www.researchgate.net/publication/314689713_Fengshui_Elemen_Budaya_Tionghoa_Tradisional
} 
Tionghoa-Indonesia, terutama Tionghoa-Banyumas dengan asumsi bahwa Bongpay merupakan bagian dari teks budaya yang memiliki keterkaitan antara etnis Tionghoa sebagai kreatornya serta relevansi respon masyarakat terhadap keberadaan mereka di Indonesia. Adapun pendekatan yang digunakan adalah metode hermeneutika ${ }^{16}$ dengan fokus kajian pada tiga aspek berupa : teks (Bongpay di Bong Muntang-Tanjung Banyumas), pencipta (Tionghoa-Indonesia), dan responden (Masyarakat Indonesia), sebagaimana digambarkan pada bagan berikut ini;

\section{Bagan I}

Metode Hermeneutika (Ratna, 2010: 46)

\section{Teks}

\section{Pengarang}

\section{Pembaca}

Berpedoman pada bagan tersebut, Bongpay diposisikan sebagai teks literal yang dapat ditafsirkan sepertihalnya karya sastra. ${ }^{17}$ Pendekatan ini digunakan dengan tujuan mengoptimalkan tafsiran identitas Tionghoa-Indonesia berdasarkan artefak kebudayaan dengan mempertimbangkan pandangan masyarakat Indonesia terkait keberadaan mereka. Akhirnya, melalui kajian ini diharapkan mampu menafsirkan pergeseran identitas TionghoaBanyumas sebagai bagian dari Identitas Tiongho-Indonesia berbasis pada tipologi Bongpay dengan mempertimbangkan unsur eksistensi etnis Tionghoa dan relevansi pandangan masyarakat Indonesia terhadap mereka.

\section{B. PEMBAHASAN}

Pergeseran Identitas Tionghoa-Indonesia pada umumnya, maupun TionghoaBanyumas tidak luput dari dinamisasi pergeran Tionghoa-Asia Tenggara, sebagaimana telah dijabarkan dalam teori multiidentitas. Hal ini nampak dalam tradisi penghormatan leluhur yang menjelaskan pentingnya relasi dan harmonisasi antara mendiang dengan keturunannya.

\footnotetext{
${ }^{16}$ Hermeneutika merupakan teori dan metode ilmiah tertua semenjak zaman Plato dan Aristoteles, yangmana terfokus pada interpretasi, pemahaman, verstehen, dan retroaktif. Teori dan metode ini tidak mencari makna yang benar, melainkan makna paling optimal. Dalam menginterpretasikan, untuk menghindarkan keterbatasan proses interpretasi seorang peneliti menitikberatkan pada pruralisme horison dan paradigma berbeda. Melalui keragaman pandangan pada gilirannya menimbulkan kekayaan makna dalam kehidupan manusia, menambah kualitas estetika, etika, dan logika (Ratna, 2010, hal. 4446).

${ }^{17}$ Ibid
} 
Leluhur senantiasa kekal mengayomi keturunannya dan wajib untuk dihormati. Realisasi ini tercermin dalam tradisi pemakaman dan puncaknya pada Bongpay sebagai lambang ikatan antara mendiang dengan keturunannya. Penafsiran terhadap Bongpay di Bong MuntangTanjung Banyumas sebagai lambang pertalian keluarga dikaitkan dengan kosmologi Fengshui atau Hong-shui, tipologi Bongpay, serta relevansi respon masyarakat Banyumas terhadap eksistensi Tionghoa-Banyumas.

1) Kosmologi Feng-shui dalam penentuan letak maupun posisi Bong MuntangTanjung,

Komplek Bong Muntang terletak di kelurahan Tanjung, Kecamatan Purwokerto Selatan, Banyumas, Jawa Tengah dengan titik koordinat $7^{\circ} 26^{\prime} 42^{\prime \prime S} \quad 1^{\circ} 9^{\circ} 13^{\prime} 16^{\prime \prime} \mathrm{E}$ dan berdiri pada tahun 1823 dengan luas areal \pm 8 hektar. Secara umum, tipologi Bong Muntang TanjungBanyumas tidak terlepas dari kosmologi Feng-shui sebagai bagian dari ajaran Tridarma; Konfusianisme, Taoisme dan Budhisme, yangmana terdapat simbol dan lambang-lambang idealisme kehidupan sebagaimana disebut dengan filosofi Tien-Yuan-Ti-Fang ${ }^{18}$. Filosofi ini menjelaskan bahwa langit itu bundar dan bumi itu persegi. Bundar melambangkan ketidak teraturan sifat alam dan persegi melambangkan keteraturan dan intelektualitas manusia sebagai manifestasi penerapan keteraturan atas alam. Kedua unsur tersebut bergabung dan merujuk pada filosofi Tien-Yen-Chih-Chi ${ }^{19}$ yang mengambarkan diantara langit dan manusia, terdapat peralihan dua alam dengan simbolisasi bentuk: bundar - segi empat - bundar. Sementara itu, konsep kehidupan diatur oleh dualitas Yin dan Yang dan Feng-shui /Hong-shui. Dalam hal ini penerapan kedua konsep tersebut bertujuan untuk mendapatkan keselarasan hidup dengan memanfaatkan gaya-gaya alam dari bumi dan menyeimbangkan Yin dan Yang guna mendapatkan $Q i$ yang baik. Selain $Q i$, terdapat lima unsur dalam Hong-shui yang diperhatikan; (1) kelahiran, (2) kondisi tanah pada lokasi, (3) arah dan ukuran, (4) orientasi ruang, (5) serta pola.

Senada dengan konsep Feng-shui, posisi makam di Bong Muntang-Tanjung Banyumas mengikuti aturan membelakangi bukit dan menghadap wilayah lebih rendah, serta berhadapan dengan pemukiman. Selain itu, kesesuaian sanitasi menjadi pertimbangan utama sebagai simbol kelancaran kekayaan dan kesehatan bagi generasi penerus. Selanjutnya, ritual perhitungan tanggal pembuatan makam, masih menjadi keutamaan dalam menentukan

\footnotetext{
${ }^{18}$ raziq_hasan.staff.gunadarma.ac.id/Downloads/files/13338/ARSITEKTUR+CINA.pdf

${ }^{19}$ Ibid
} 
peletakan batu pertama makam dengan memperhatikan ketepatan ukuran peti mati, kedalaman tanah, maupun kemiringan gundukan tanah sebagai penanda posisi kepala.

\section{2) Tipologi Arsitektur Bongpay dalam Tradisi Tionghoa Kuno di Bong Muntang- Tanjung Banyumas,}

Pandangan Yin dan Yang serta Feng-shui/Hong-shui sebagai dasar filosofi Tionghoa terimplementasi dalam konstruksi setiap bangunan, tidak terkecuali makam. Karena makam merupakan bagian penting dalam tahapan kehidupan sepertihalnya hunian. Hal ini dibuktikan pada tipologi arsitektur Bongpay di Bong Muntang-Tanjung Banyumas yang bercirikan pada; (1) Kepatuhan terhadap konsep Tien-Yuan-Ti-Fang yaitu konsep langit itu bundar dan bumi persegi yang diimplentasikan pada bentuk papan nisan dan makam, (2) Kepatuhan terhadap bagian-bagian Bongpay (Mu-qui, Mu-an qian kao, Mu-an hou kau, Mujian, Qu-shou/Mu-shu, Hou-Tu, dan Mucheng), (3) Dualisme Yin dan Yang, (4) Kosmologi Feng-shui atau Hong-Shui yang senantiasa menonjolkan lima unsur dan terwujud dalam struktur sequensial horisontal maupun hirarki konsentris pada Bongpay, (5) Adanya kombinasi unsur warna alam yang mencolok meliputi; merah, kuning/emas, hijau, biru, putih/perak, dan hitam, (6) Harmonisasi struktur dasar makam yang masih mengikuti konsep Tridarma melalui formalitas Bongpay yang berbentuk simetris dengan perpaduan garis lurus serta beraturan sebagaimana konsep Konfusius, sedangkan garis lengkung dan naturalis mencerminkan ajaran Taoisme, dan lapisan berundak ataupun bergelombang sebagai implementasi ajaran Budhisme, (7) Penggunaan material batu alam sebagai simbol status sosial, (8) Posisi mata Bongpay pada ujung kaki mendiang sebagai penanda penghormatan pada leluhur, (9) Perbedaan tinggi gundukan tanah sebagai penanda posisi kepala mendiang (asimetris sesuai ajaran Taoisme), (10) Penekanan pada konsep vertikal-horisontal sebagai penjelasan hukum langit dan bumi, (11) Adanya altar pemujaan di bawah papan nisan, (12) Penggunaan ornamen-ornamen mitologi Tionghoa meliputi: hewan, tumbuhan, ataupun dewa-dewi Tionghoa, (13) Penggunaan karakter Fantizi (繁体字) atau Hanzi kuno pada papan nisan yang menjelaskan identitas mendiang secara detail beserta kota asalnya di Tiongkok. 


\section{Gambar 1}

Tipologi Bongpay Tionghoa Kuno di Bong Muntang-Tanjung Banyumas
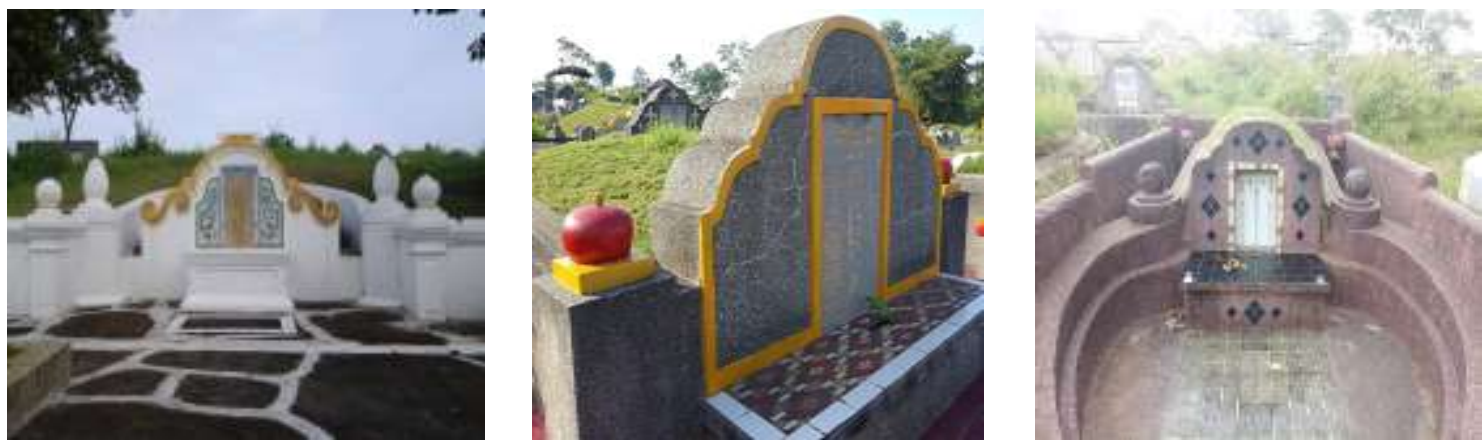

\section{3) Tipologi arsitektur makam Eropa yang diadopsi oleh Tionghoa-Indonesia di Bong Muntang-Tanjung Banyumas}

Logika sebagai pondasi rasionalitas masyarakat dunia sebagaimana dibawa oleh pandangan barat dalam periodisasi kolonialisme dan imperialisme, turut berdampak pada perubahan sosial-budaya Indonesia, terutama etnis Tionghoa. Hal ini merujuk pada sejarah keberadaan etnis tersebut untuk bersikap rasional dan setara sejalan dengan konsep Renaissance dari barat yang bersifat universal melalui ajaran Kristus. Hasilnya, dimensi agama yang dibawa oleh misionaris barat mampu berperan dalam transformasi budaya dan identitas Tionghoa-Indonesia.

Implementasi modernitas Tionghoa-Indonesia berbasis pada budaya barat, tercermin dalam tradisi sosial-budayanya, sepertihalnya dalam perubahan tipologi makam TionghoaBanyumas yang meyakini ke-Esaan Kristus berupa: (1) Kesalehan terhadap ajaran Kristus sebagai agama yang dianut, (2) Kesederhanaan bentuk dengan fokus meruncing ke atas (surga), (3) Posisi papan nisan berada diatas kepala mendiang, (4) Papan nisan merepresentasikan bentuk tempat-tempat sakral, sepertihalnya gereja dan katedral, (5) Pola tanah makam datar dan simetris mengikuti struktrur dasar peti mati sebagai simbol kesetaraan, (6) Penekanan pada gaya arsitektur Gotik dan Romanesque sebagai wujud Rennaissance dengan ciri: (a) menjulang tinggi sebagai representasi aspirasi dan harapan terhadap surga, (b) berujung lancip ataupun setengah lingkar, (d) bentuk geometri, (d) terdapat lengkungan tajam atau Vault, (7) Penekanan estetika yang bertumpu pada dekorasi dan ornamen religi seperti (salib, patung atau gambar Kristus, santa maupun peri, graviti perjamuan abadi, dsb), (8) Dominasi warna tunggal dan umumnya hitam, (9) beralfabet latin yang menjelaskan identitas mendiang beserta keluarga dengan nama-nama babtis. 


\section{Gambar 2}

Tipologi Makam Kristen-Katolik Tionghoa-Indonesia di Muntang-Tanjung Banyumas
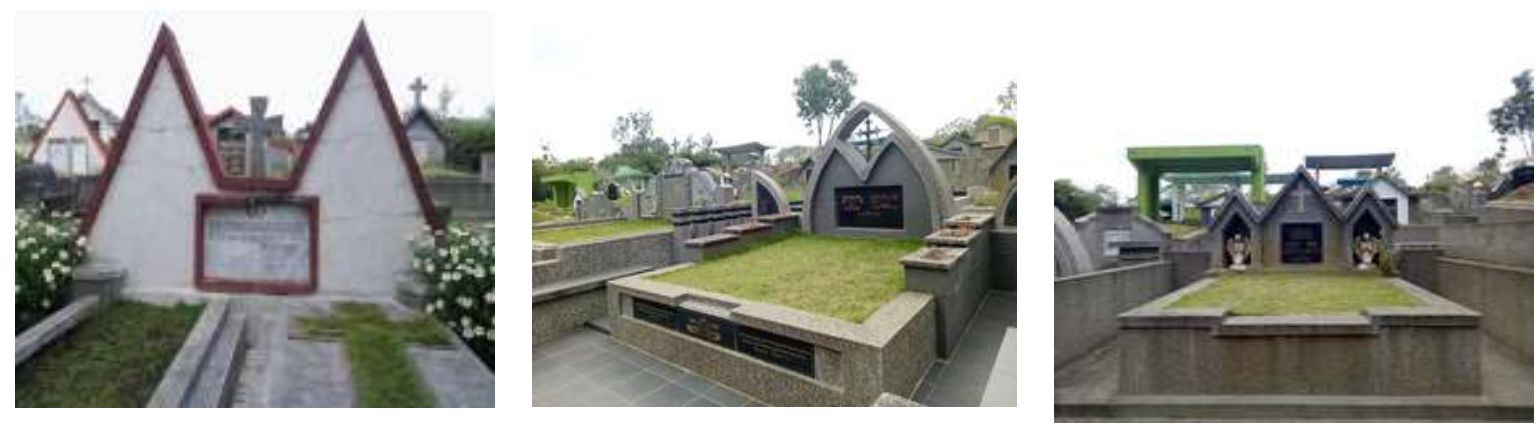

\section{4) Pengaruh Budaya Barat Pada Tipologi Bongpay Tionghoa-Indonesia di Bong Muntang-Tanjung Banyumas}

Rasionalitas ajaran barat yang mengedepankan konsep setara dan universal telah merubah mind-set Tionghoa-Indonesia kini dan menjadikannya sebagai pandangan hidup modern. Modernitas tersebut menjadi landasan perubahan tradisi budaya Tionghoa-Indonesia sebagai bagian dari masyarakat dunia yang setara dengan golongan lainnya. Meskipun demikian, mereka tidak serta merta meninggalkan tradisinya, terutama terkait dengan konsep pertalian dan penghormatan leluhur. Hal ini nampak pada tradisi pemakaman yang masih bernuansa Tionghoa, sebagaimana tergambar pada beberapa Bongpay Tionghoa-Indonesia di kawasan Bong Muntang-Tanjung Banyumas yang bercirikan ; (1) Konsisten terhadap orisinalitas struktur dasar Bongpay Tionghoa (Mu-qui, Mu-an qian kao, Mu-an hou kau, Mujian, Qu-shou/Mu-shu, Hou-Tu, dan Mucheng), (2) Konsisten terhadap dualisme Yin dan Yang, (3) Konsisten terhadap aturan Feng-shui/Hong-shui yang menonjolkan lima unsur dan terwujud dalam struktur sequensial horisontal maupun hirarki konsentris pada papan nisan, (4) Adanya perubahan konsep Tridarma terkait Tien-Yuan-Ti-Fang kepada ke-Esaan Tuhan dan keberadaan surga (5) Adanya perubahan harmonisasi struktur dasar makam berkonsep Tridarma, melalui hilangnya garis lengkungan tajam yang mencerminkan ajaran Taoisme, serta lapisan bertingkat maupun bergelombang dalam ajaran Budhisme, (6) Konsistensi penggunaan material alam, (7) Konsistensi pada struktur dasar Bongpay kuno, (8) Adanya kesamaan tinggi gundukan makam, (9) Konsistensi vertikal-horisontal sebagai lambang langit dan bumi, (10) Konsistensi terhadap keberadaan altar pemujaan, (11) Adanya kombinasi ornamen Tionghoa dengan ornamen Kristus, (12) Adanya perubahan karakter Fantizi 繁体 字) ke alfabet latin, dan 13) Adanya variasi nama dalam tiga bahasa (Tionghoa, Indonesia, dan Baptis). 


\section{Gambar 3}

Pengaruh Budaya Barat dalam Tipologi Makam Tionghoa-Indonesia di Bong Muntang-Tanjung Banyumas
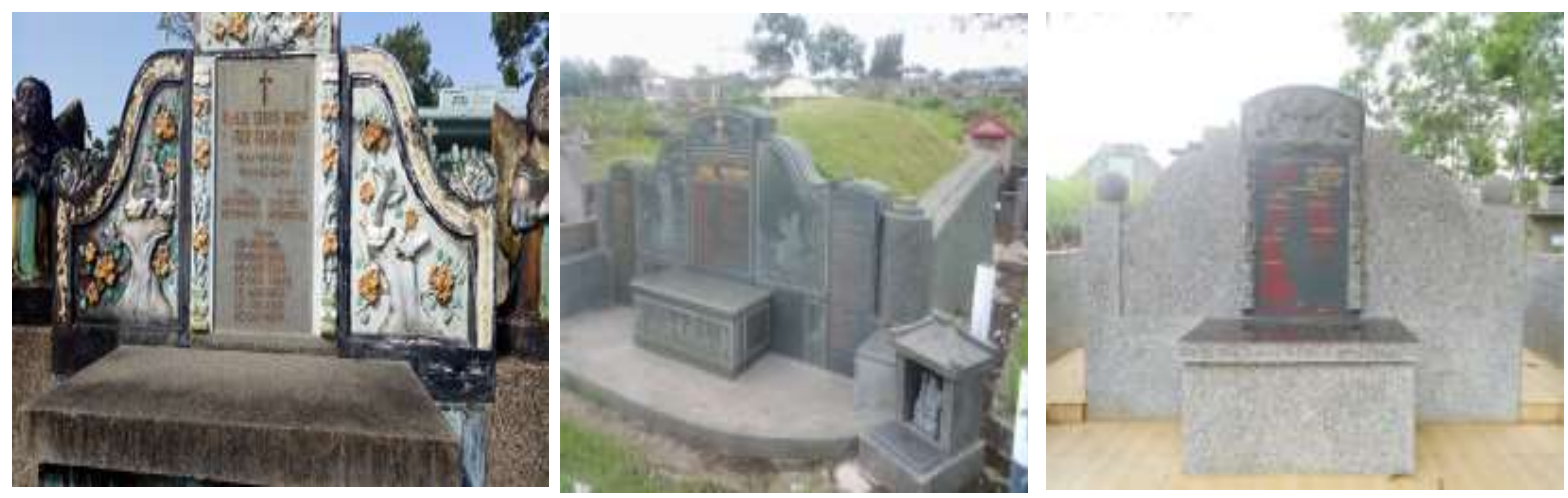

\section{5) Pengaruh Budaya Barat dalam Pergeseran Identitas Tionghoa-Indonesia Melalui Hermeneutika Bongpay di Bong Muntang-Tanjung Banyumas}

Identitas sebagai sistem refleksi resiprokal terhadap jati diri manusia tercermin pada identitas Tionghoa-Indonesia yang tentunya berbeda dengan identitas Tionghoa daratan. Perbedaan ini dipengaruhi oleh interaksi mereka terhadap identitas lain sebagaimana identitas Indonesia terbentuk melalui interaksi dengan budaya; India, Arab, maupun Eropa. Disini, wujud interaksi tersebut tercermin pada variasi Bongpay di Bong Muntang-Tanjung Banyumas.

Berbasis pada metode hermeutika atau metode yang menekankan pada optimalisasi makna melalui keragaman penafsiran, Bongpay di Bong Muntang-Tanjung Banyumas diposisikan sebagai teks representatif terkait eksistensi etnis Tionghoa-Indonesia. Sementara itu, totalitas signifikansinya juga turut dipengaruhi oleh relevansi pandangan masyarakat Banyumas terkait dengan keberadaan etnis tersebut. Secara umum totalitas penafsiran Bongpay di Bong Muntang-Tanjung Banyumas sebagai cerminan pergeseran identitas Tionghoa-Indonesia digambarkan melalui bagan berikut ini; 
Bagan II

Penerapan Metode Hermeneutika dalam Analisis Pergeseran Identitas TionghoaIndonesia melalui Bongpay di Bong Muntang-Tanjung Banyumas

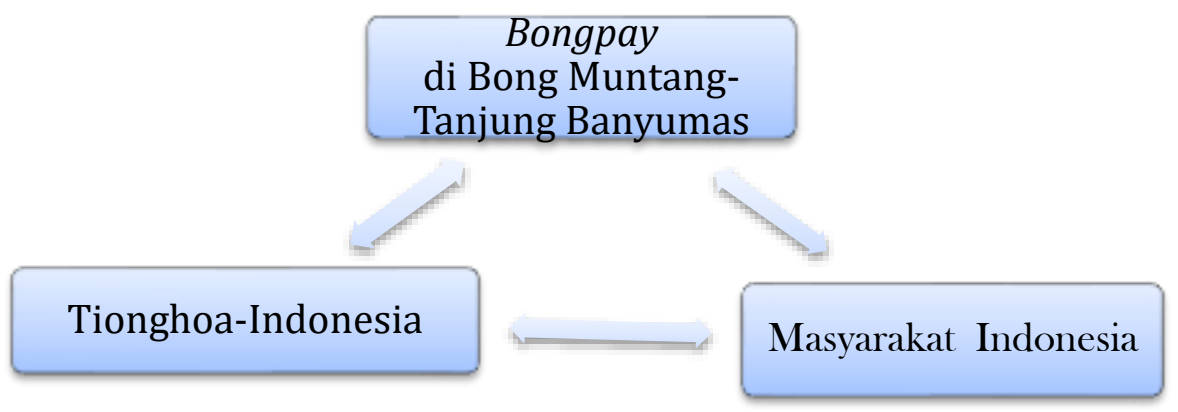

Merujuk pada bagan di atas, penafsiran awal dimulai dengan mengkaji etnis TionghoaBanyumas sebagai bagian dari Tionghoa-Indonesia dan respon masyarakat Banyumas. Identifikasi kedua hal ini menjadi kunci pembentukan identitas Tionghoa-Banyumas, yangmana keberadaan etnis tersebut sudah ada sebelum abad ke-18 seiring dengan keberadaan kawasan pecinan disepanjang jalan utama kota. Hal ini didukung oleh keberadaan klenteng Hok Tek Bio Pasar Wage, Hok Tek Bio Sukaraja, dan Hok Boen Tek Bio Banyumas sebagai pusat perkembangan etnis Tionghoa-Banyumas yang bergerak pada sektor perdagangan maupun industri jasa. Keberadaan dari klenteng-klenteng tersebut merupakan ekspresi dan apresiasi etnis Tionghoa-Banyumas terhadap ajaran Tridarma yang senantiasa menghubungkan mereka dengan tradisi dan tanah leluhur.

Keberadaan klenteng-klenteng di wilayah Banyumas turut berkontribusi pada perkembangan sosial-budaya Banyumas, yangmana konsep Tridarma sanggup bersinergi dengan masyarakat Banyumas terkait dengan alam. Alam sebagai sektor utama kehidupan masyarakat Banyumas menjadi relevansi eksistensi Dewa Bumi sebagai penguasa yang senantiasa wajib untuk dihormati. Kesaman konsep ini turut membentuk jatidiri TionghoaBanyumas dan masyarakat Banyumas yang terwujud dalam akulturasi kebudayaan sepertihalnya: Masjid Cheng-Ho di Purbalingga, Nopia, Soto Sukaraja, Jenang Jaket, Batik Sukaraja, Calengsay, dsb. Kebudayaan ini merupakan wujud integrasi etnis Tionghoa dengan masyarakat Banyumas yang kini membentuk identitas mereka sebagai bagian dari masyarakat Banyumas.

Berbasis pada alam sebagai unsur kehidupan dan berharmonisasi dengan masyarakat Banyumas untuk mengakulturasikan kebudayaan antar etnis dalam rangka membentuk kebudayaan Banyumas, menjadi penanda utama identitas Tionghoa-Banyumas. Melalui hal ini nampak bahwa identitas Tionghoa-Banyumas identik dengan karakteristik masyarakat 
setempat sebagai bagian dari masyarakat Banyumas. Pada tahap selanjutnya, identitas ini bersinergi terhadap perubahan struktur sosial dan politik Indonesia. Hal ini disebabkan oleh politik asimilasi dan penghapusan tradisi Tionghoa pada era Orde-Baru yang turut berdampak pada perubahan identitas Tionghoa di wilayah Banyumas. Hasilnya, saat ini identitas Tionghoa-Banyumas bercirikan karakteristik masyarakat Banyumas, tanpa meninggalkan ajaran Tridarma sebagai bagian dari tradisi leluhur yang berharmonisasi dengan kesalihan terhadap Tuhan YME dan terwujud pada diferensiasi tipologi Bongpay di Bong Muntang-Tanjung Banyumas.

Merujuk pada perbedaan-perbedaan tipologi Bongpay di Bong Muntang-Tanjung Banyumas pada akhirnya turut menjelaskan pola pergeseran identitas Tionghoa-Banyumas. Pola pergeseran tersebut nampak melalui tipologi Bongpaynya, yangmana pada (a) tipologi pertama mengungkapkan totalitas identitas Tionghoa berdasarkan pada penggunaan karakter Fantizi (繁体字) atau Hanzi kuno sebagai penjelasan asal-usulnya di Tiongkok dan kepatuhan terhadap aturan Tridarma, (b) tipologi kedua mengungkapkan perubahan identitas Tionghoa berorientasi barat (renaissance) dengan adanya ajaran Kristus yang mengutamakan kemanunggalan dan kesetaraan melalui replika Gereja maupun Katredal bergaya Gotik dan Romanesque sebagai bentuk dasar Bongpaynya. Selain itu penulisan dalam huruf latin dan nama-nama Baptis menjelaskan transformasi identitas Tionghoa bergaya barat, dan (c) tipologi ke-tiga merupakan perpaduan tradisi, yangmana terdapat pola harmonisasi antara Tridarma dan Kesalehan pada Tuhan YME dengan berorientasi pada ajaran barat.

\section{Kesimpulan}

Identitas sebagai sistem refleksi resiprokal terhadap jati diri manusia tercermin pada identitas Tionghoa-Indonesia yang tentunya berbeda dengan identitas Tionghoa daratan. Perbedaan ini dipengaruhi oleh interaksi mereka terhadap identitas lain sebagaimana identitas Indonesia terbentuk melalui interaksi dengan budaya; India, Arab, maupun Eropa. Dalam hal ini terwujud dalam diferensiasi Bongpay di Bong Muntang-Tanjung Banyumas dengan ciri utama; (1) Bongpay bertipologi Tionghoa kuno, (2) Bongpay bertipologi barat, dan (3) Pengaruh budaya barat dalam tipologi Bongpay. Melalui diferensiasi tipologi Bongpay tersebut, memberikan gambaran mengenai diferensiasi identitas Tionghoa-Banyumas sebagai bagian dari Tionghoa-Indonesia yang masih berorientasi pada harmonisasi antara tradisi dengan modernitas melalui pandangan barat. 


\section{DAFTAR PUSTAKA}

Bruun, Ole. 2008. An introduction to Feng-shui. New York: Cambridge University Press.

Budianta, Melani. 2008. Aspek Lintas Budaya dalam Wacana Multikultural. Dalam Prosiding Seminar Kajian Wacana dalam Konteks Multikultural dan Multidisiplin FIB UI.

Cristian, Symphoni Akelba. 2017. Identitas Budaya Orang Tionghoa Indonesia. Dalam Jurnal Cakrawala Mandarin Vol.1, No. 1 April 2017

Dahana, A. 2000. Kegiatan Awal Masyarakat Tionghoa di Indonesia. Dalam Jurnal Wacana Vol 2. No.1 April 2000

Fung, Yu-Lan. 1960. Sejarah Pendek Filsafat Tiongkok. Yogyakarta : Taman Siswa.

Hecht, Jackson, 2003. Culture Identity. California: Sage Publications.

Hermawan, Robby,dkk. 2015. Penerapan Fengshui dan Pandangan Fengshui dari Anak yang Menyemayamkan Orang Tuanya di Pemakaman Puncak Nirwana. Dalam Student Jurnal.petra.ac.id/index.php/sastra-tionghoa/article/download/2705/2419

Huda, Samsul. 2010. Orang Indonesia - Tionghoa dan Persoalan Identitas. Dalam Jurnal Kontekstualita: Jurnal Penelitian Sosial Keagamaan Vol.25, No. I Mei 2010

Ibrahim, 2012. Tionghoa-Indonesia: Dari Dikotomi ke Mono- Identitas? Dalam Jurnal Ilmu Komunikasi Volume 10 No.10 Januari 2012

Jiang, Rinto. 2006. Tata-cara Penulisan Nisan (Bongpay) Tradisional Tionghoa. Dalam Studying Indonesian-Chinese Culture. Publikasi pada 17 Agustus 2006.

Khaelish, Hamdil. 2015. Arsitektur Tradisional Tionghoa: Tinjauan Terhadap Identitas, Karakter Budaya dan Eksistensinya. Dalam Jurnal Fakultas Tekhnik Tanjung Pura Vol. 1.No 1 Agustus 2015

Kustedja, Sugiri dkk. 2012. Feng-shui: Elemen Budaya Tionghoa Tradisional. Dalam ResearchGate.

https://www.researchgate.net/publication/314689713_Feng-hui_Elemen_Budaya_Tionghoa_Tradisional.

Diakses pada tanggal 21 Juli 2017

Lubis, Lusiana-Adriani. 2012. Komunikasi Antar Budaya Etnis Tionghoa dan Pribumi Medan dalam Jurnal Ilmu Komunikasi Volume 10. No 1 April 2012

Murtadlo, Muhamad. 2013. Budaya dan Identitas Tionghoa Muslim di Kalimantan Barat. Dalam Jurnal Lektur Keagamaan Vol. 11 No. 2, 2013 : 2013- 308

Priscillia, Sasmita, dan Lintu Tulistyantoro. 2014. Pergeseran Tradisi Pemujaan Leluhur Dalam Hubungannya Dengan Organisasi Ruang Rumah Tionghoa Saat Ini di Surabaya.Dalam Jurnal Desain Interior 2013/2014 Vol 2, No 2

Raharjo, M. 2012. Memilih Lokasi Makam Terbaik. Dalam http://www.rumah.com/beritaproperti/2012/9/1733/menentukan-arah-hadap-makam 25-3-2016

Raharjo, M. 2013. Fengshui Terapan. Jakarta : PT Elex Media Computindo.

Ratna, Nyoman Kutha. 2010. Metodologi Penelitian: Kajian Budaya dan Ilmu Sosial Humaniora Pada Umumnya. Yogyakarta: Pustaka Pelajar

Sulaiman, 2009. Agama Khonghucu Sejarah Ajaran dan keorganisasiannya di Pontianak kalimantan Barat. Dalam Jurnal Analisa Volume XVI, No.1 edisi Januari-Juni 2009. 
Suryadinata, Leo. 2003. Kebijakan Negara Indonesia Terhadap Etnik Tionghoa: Dari Asimilasi ke Multikulturalisme. Dalam Jurnal Antropologi Indonesia, edisi ke-71 Tahun 2013.

Wibowo, Priyanto. 2012. Tionghoa dalam Keberagaman Indonesia: Sebuah Perspektif Historis Tentang Posisi dan Identitas dalam Prosiding the $4^{\text {th }}$ Internasional Conference On Indonesian Studies: Unity, Diversity and Future". Jakarta: Universitas Indonesia

Yau-HOON, Chang. 2012. Identitas Tionghoa Pasca-Suharto: Budaya, Politik, dan Media. Jakarta:

Yayasan Nabil dan LP3ES.

http://fadhil-nugroho.blogspot.co.id/2012/04/jurnal-stratifikasi-sosial-bahan-dukung Diunduh pada tanggal 17 Juli 2017

http://digilib.mercubuana.ac.id/manager/n!@file_skripsi/Isi1893295104511.pdf. Diunduh pada tanggal 19 Juli 2017 https://www.britishmuseum.org/pdf/Chinese_language_1109.pdf diakses pada 18 juli 2017,18.00 WIB raziq_hasan.staff.gunadarma.ac.id/Downloads/files/13338/ARSITEKTUR+CINA.pdf. Diakses pada tanggal 30 Juli 2017

\section{Data Penulis}

$\begin{array}{ll}\text { Nama } & : \text { Tri Asiati } \\ \text { Prodi } & : \text { D3 Bahasa Mandarin UNSOED } \\ \text { Perguruan Tinggi } & : \text { Universitas Jenderal Soedirman (UNSOED) } \\ \text { Status } & : \text { Staf Pengajar Pengantar Budaya Tionghoa } \\ \text { HP } & : \text { +621804088492 } \\ \text { Email } & : \text { asiatitri@yahoo.com }\end{array}$

